\title{
1. Ideas of justice
}

'It belongs in utopia', said Imogene. This was our third and last conversation. It had been over three years since the assault on her. My final question to her was 'after everything, what now is your idea of justice?' She said (in part), 'I'd have to say it's an ideal. It belongs in utopia. It shouldn't but it does. If it does exist it is more a lottery. It's not what I believe but it's what happens in practice.' (Imogene, 2013)

In a different place and time, during an interview with an ex-Director of Public Prosecutions, I asked a slightly different question - though I was trying to get at a similar concern. I asked, 'What was the conception of justice you carried in your working life as a prosecutor?' The reflection was (in part), 'the requirements of justice point in different ways which makes it difficult to define it in any comprehensive way. (P3, 2011)

This book sits in an extended conversation about the idea of justice, who has it, who does not and what it means in the everyday setting of criminal justice. It challenges the usual representation of people victimized by violence only as victims, and challenges conventional legal approaches that contain their aspirations for justice. The argument of this book is for inclusion of those with directly affected interests as a first principle of institutions in a democratic society. While the book focuses on people as victims of violence and their involvement with criminal justice, it argues that deliberation with victims and offenders is indispensable to an approach that centralizes the realization of justice as a core value in their lives. What is the nature of this hoped-for justice is considered in the following chapters.

From 1996 to 2011 I worked as an independent statutory advocate for victims' rights. ${ }^{1}$ Reflections about justice such as those introducing this

1 Pursuant to Victims of Crime Act 1994, s.14 as the Victims of Crime Coordinator (VoCC) for the Australian Capital Territory (ACT). The position was an appointment of the Attorney General. As an independent statutory position the VoCC combined the promotion of victims' rights and investigation of breaches of rights. I was appointed in 1996 and served with successive appointments until 2011. I was instrumental in two major reforms to the legislation. Briefly, the first reform brought services for victims under the responsibility of the VoCC, and the second saw the position (and its powers) changed to that of a Victims of Crime 
chapter were commonplace. My daily interactions with victims of all types of offences involved in various justice processes revealed their bewilderment with a system they thought they would know. Equally, innumerable discussions and debates with judicial officers, prosecutors, police, victim advocates, probation and correctional officers, policy makers and law reformers about the role and rights of victims served to emphasize as many perspectives as there were operational areas to justice. Justice was clearly important to everyone but were we all talking about the same thing?

I came to realize that people victimized by violence who engage with the criminal justice system talked in complex ways about the idea of justice. Listening to their many voices suggested to me that justice was about a whole host of things, just as their identity was more than that of victim. Much of this, however, was hidden from view by the way people as victims were excluded, ignored or diverted. This seemed to me to be a loss. As a 'victim' they were seen as a problem for law to manage and contain. This created other types of loss. Instead I came to understand that victimization and the mobilization of the criminal law in response presented a unique opportunity to cultivate 'the capacity of citizens to rise to the demands of justice in their own political lives'. ${ }^{2}$ An opportunity that not only considered what had happened and what should happen next, but also to debate and deliberate the issues that confronted both victim and offender, and the social, political, economic and cultural aspirations they held for themselves and for others. The usual approach is the allocation of justice in a particular distributive pattern with parties as passive recipients of decisions made by legal professionals in a context where state institutions maintain an ideology of hegemony. Another is to see the opportunity provided in a sequence of procedural and institutional spaces for citizens to produce justice.

This book aims to describe and understand this capacity of citizens, and to consider the implications within this institutional "culture of control'. It is not a book about retributive or restorative or any other particular way of doing justice. Neither is it a book that settles questions of what victims want or victims' needs after violence. Rather, it presents argument that the mobilization of the criminal law in response to victimization and subsequent engagement with criminal justice processes

Commissioner. The administration of justice involves diverse processes in police, prosecution, courts and tribunals, probation and corrections, and encompasses youth and adult jurisdictions as well as criminal and civil areas of law.

2 Austin Sarat and Thomas R Kearns, Justice and Injustice in Law and Legal Theory (U Michigan P 1996) 17. 
are practices arising from and an enactment of people's membership of a political community, a community of citizens; practices that contribute to governance. They are citizenship activities founded on peoples' justice interests rather than an articulation of their justice needs. As citizens, the justice they seek is that which is due to all.

\section{DIFFERENT TALES, ONE STORY}

Of course, as I heard in my working life and discovered anew during the research conducted for this book, there are many tales in the story of justice. In one such are the vast majority of victims of crime who vote with their feet and do not engage with authorities, particularly if the offence against them involves physical or sexual violence. Part of this version, extensively told, is about the structured alienation of people from access to justice. Another tale is about the astonishingly rare people who report the incident to police and who then see that case proceed through the criminal justice system. While an individual may be propelled by the circumstances of the victimization to report to authorities, there is no coercion to do so. This tale commonly tells of hurdles, barriers and casual discourtesies.

A different thread speaks of those who believe (albeit tentatively) that a wrong may - or perhaps should - be recognized; where they, with their torn human dignity, will be treated with respect and where fairness is paramount. At this point of the tale different interests and influences converge, conflate and conflict. Yet in this particular story ordinary people perhaps reasonably assume that the meaning both of rights and their status as citizens will be recognized. Indeed, that these two aspects of their social and political identity will be foundational to the way the system will operate, whether responding to them as victim or as offender. Embedded within the telling is a perspective that the system is designed to deliver justice, 'pure and simple', for all its citizens. ${ }^{3}$ Indeed, that the system, as an embodiment of the state, is somehow a partner to them all - victim, offender and community - in that honourable purpose. This story is about how justice is valued in the wider social world.

Is this a fairy tale? Across the common law world in Australia, the United Kingdom (UK), the United States (US) and elsewhere so bruising are people's actual encounters, so taxing the process and so disappointing are its outcomes that a very real question hangs over what could be

\footnotetext{
3 Ibid., 2.
} 
described as fanciful expectations. So the idea and ideal of justice leads the book's enquiry. It is examined mainly through the eyes of ordinary people but also through the narratives of legal officials. Rather than a philosophical ideal, it seeks an idea of justice in the real world. For the people in this study - ordinary and official - justice mattered very much.

The stories of these two groupings are often posed in counterpoint. Nils Christie famously charged the state and its agents as thieves of the private disputes of citizens. ${ }^{4}$ This critique precipitated calls for complete or partial redesign of state-administered criminal justice. It also, in part, led to an explosion of interest in different approaches to and mechanisms for delivering justice. One activity that has come to dominate this area is restorative justice. While it is a diverse field, restorative justice commonly claims to return the dispute to private citizens. This book takes a different tack. Rather than see the 'dispute' as one thing or the other, I argue that it is defined and co-determined by private and public interests. As such it is brought by citizens into the public realm because it is a public space with particular and unique characteristics. In so doing, these citizens ask for deliberation on the nature of the conduct alleged and a determination on its wrongfulness to standards contained in the criminal law. They do so for a combination of personal and public policy reasons. By undertaking this engagement they make a contribution to public governance. This perspective views people as victims less as a law problem and more as social, political and legal actors.

\section{THE CONTESTED PLACE OF VICTIMS IN JUSTICE}

My arguments speak back to academic and policy debates where people as victims are presented either as 'a favoured constituency' driving redefinition of criminal justice ${ }^{5}$ or as a 'pariah' to that same system ${ }^{6}$ notwithstanding that they are also institutionally irrelevant. ${ }^{7}$ Within these boundaries and in the domestic criminal justice environment of liberal

4 Nils Christie, 'Conflicts as Property' (1977) 17 The British Journal of Criminology 1.

5 David Garland, The Culture of Control: Crime and Social Order in Contemporary Society (OUP 2001) 121.

6 Paul Rock, 'New Labour Policies for Victims' (2007) 67 Criminal Justice Matters 38, 39.

7 Doreen McBarnet, 'Victim in the Witness Box - Confronting Victimology's Stereotype' (1983) 7 Contemporary Crises 293. 
democracies, legal and conceptual recognition of victims is mired in endless controversy.

The irrelevance of victims to criminal justice in common law jurisdictions was not always the case. The centuries-old practice whereby victims had initiation and carriage of prosecution in England and Wales made the transport to the Australian colonies where much of the research that informs this book was undertaken. But in the modernist epic, bureaucratic centralization and professionalization was as rapid in Australia as it was episodic and inexorable at the centre of Empire. By the twentieth century, in both countries, people as victims had become instruments for institutional ends. Rationalizing this process involved weaving different historic threads into a blanket account of an abstract and universal 'public' owning the common good and the state's agents owning its definition. More recently, people victimized by crime have come to make a trenchant critique of their exclusion and thereby to question how that public is constituted and considered. They claim the system could not function without them. It is this person, group or entity who suffers the intrusion, articulates the violation, decides whether and how to inform and cooperate with formal or informal authorities, provides primary evidentiary and forensic information, is interrogated as a witness and is offered in validation (or not) of the outcome. They are also a part of the public.

This person, however, is subjected to innumerable indignities - as is the individual accused - in a system that espouses principles of respect, rights and equal treatment. These indignities do not appear by happenstance but are manifest as statements of institutional authority. Prior policy and academic debate has probed this disregard. In particular, critical scholars have found wanting the differential ways the law and its practice, as well as practitioners and institutions, dealt with particular offences and associated characteristics of victims such as their gender, age, sexuality, ethnicity or race. For many individuals and communities, the law is both over-applied and under-used. However, I argue that these characteristics are secondary to the primary structural and conceptual exclusion of persons as victims from criminal justice.

This exclusion is not globally uniform. Looking back in history as well as looking sideways to inquisitorial and other legal systems, more recent argument has emerged seeking recognition of victims with inherent civil and human rights, and - controversially - as parties. ${ }^{8}$ At the level of

8 Jonathan Doak, Victims' Rights, Human Rights and Criminal Justice: Reconceiving the Role of Third Parties (Hart 2008). 
international criminal justice and in post-conflict justice, initiatives there have been rapid and radical adjustments made over the past 20 years to recognize, respect and represent victims..$^{9}$ In these domains it is possible to assert that 'victims are at the heart of human rights thinking'. ${ }^{10}$ This more central role for victims internationally is not undisputed ${ }^{11}$ but the changes have opened new and rich lines of scholarly reflection and advocacy about victims and justice.

The arguments for inclusion that I develop in this book, tap into the general tide of discontent with and alienation from institutions of democracy and governance. Here the agitation is for participatory practices and participatory institutions that are re-centred on the inherent power of citizens. ${ }^{12}$ This agitation demands institutional humility and greater devolution of power. Participatory ideas that draw upon democratic theory have crept slowly towards criminal justice. ${ }^{13}$ Positioning victims within this space conceives them as members of the social mass - the public. This public (or 'publics') is at once singularly sovereign and plural. It can be derided as populist or lauded as the source of 'strong democracy' ${ }^{14}$ In either guise these publics ask awkward questions about accountability of authorities, in particular about the normative roots of that authority. They turn a harsh light on the representational claims that justice entities make. My argument for inclusion and participation places people as victims in a political relation to state institutions; as rights bearers in a relation with duty holders.

9 Rani Mani, Beyond Retribution: Seeking Justice in the Shadows of War (Polity Press 2004); Anne-Marie De Brouwer, 'What the International Criminal Court Has Achieved and Can Achieve for Victims/Survivors of Sexual Violence' (2009) 16 International Review of Victimology 183; Cheryl White, Bridging Divides in Transitional Justice: The Extraordinary Chambers in the Courts of Cambodia (Intersentia 2017).

10 Francesca Klug, 'Human Rights and Victims' in Ed Cape (ed), Reconcilable Rights? Analysing the Tension Between Victims and Defendants (LAG 2004) 111.

11 Brianne McGonigle Lehy, Procedural Justice? Victim Participation in International Criminal Proceedings (Intersentia 2011).

12 Carole Pateman, Participation and Democratic Theory (CUP 1970); Iris Marion Young, Inclusion and Democracy (OUP 2000); Archon Fung, 'Continuous Institutional Innovation and the Pragmatic Conception of Democracy' (2012) 44 Polity 609.

13 Albert Dzur, Punishment, Participatory Democracy and the Jury (OUP 2012); Marijke Malsch, Democracy in the Courts: Lay Participation in European Criminal Justice Systems (Routledge 2009).

14 Benjamin Barber, Strong Democracy: Participatory Politics for a New Age (U Cal P 1984). 


\section{VICTIMS AND IDEAS OF JUSTICE}

To date, however, many tales of victims and justice narrow their interests away from this broader public towards end points. In these confined spaces, assessments about justice or injustice are on the 'culmination outcome' and the influences upon it. ${ }^{15}$ From this place justice is viewed as a singular standard. Moreover, as research subjects, people as victims are commonly asked just once about their justice views and retrospectively. Confining their viewpoints and assessments in this manner leads to an impoverishment of the idea and institutions of justice. The messages that are conveyed discourage citizens from their intrinsic and highly situated complex conceptualizations. They discourage thinking that justice matters, that they matter, or that the infraction matters. These messages are personal, social and political. They communicate information about values, about who and what is important, and about where power lies and how it operates.

In this book, I move away from single representations to explore complex realizations of justice. For the Justice Study upon which this book is based, I spoke on three occasions with women and men who were victims of violence and who engaged with the criminal justice system. These were conversations held 'beneath the constitutional surface' of the law. ${ }^{16}$ Most people display a disengaged cynicism about the law and its institutions whether in Australia, Britain or elsewhere. But for those who become victims of violence this quickly becomes insupportable when they enter the portals of the criminal justice system. They have to think about what they think. They have to think about what to do, what to say, and why. Over time and in interactions with different entities, thinking about justice unfolds. Victims are informed both by the practical and the objective context in which they find themselves, as well as by their own moral and social intuitions. They become everyday philosophers of their situation.

Unsurprisingly this research approach opened space for articulating interpretations about justice that layered interpersonal, social and institutional influences. The reflections brought to light were partial, ambiguous and yet at times both firm as well as contradictory. There was nothing single or simple to victims' contemplation on the idea of justice. Their thinking was refracted through a spectrum of ideas, principles,

\footnotetext{
15 Amartya Sen, The Idea of Justice (Harvard UP 2009) 215.

16 John Dryzek, Deliberative Democracy and Beyond: Liberals, Critics, Contestations (OUP 2002) 2.
} 
rules and criteria that act as heuristics. As victims of violence, people felt acutely the presence of power and the absence of justice. For them, the shift in the meaning of justice as a utopian ideal (Imogene's comment) to 'just a word' can be jolting. ${ }^{17}$ In the rough and tumble of the real world, a malleable and more human construct appears, one that interacts with the idea of justice from a range of different positions.

\section{THE IDEA OF JUSTICE IN THE REAL WORLD}

Even as we are stimulated to look for justice, however, it emerges with an 'immense variety and complexity of meanings, applications and ideological associations'. ${ }^{18}$ Vast libraries speak to earnest and erudite depictions of justice. Much of this is abstracted and removed from the actual injustice. Injustice can be messy, bloody and painful and, as Judith Shklar has argued, justice theory tends to avoid it. ${ }^{19}$ So when I found Amartya Sen's book, The Idea of Justice, it came like the discovery of a cool pond in heated and treacherous terrain. His attention to how justice lives and moves in the real lives of ordinary people proved a refreshing draught. Sen engages with justice in its social and political dimensions. In doing so, he explicitly incorporates 'the presence of remediable injustice' as 'connected with behavioural transgressions' as well as with 'institutional shortcomings' (p. x). He suggests that justice need not be about prioritizing one good over another, nor about 'getting the basic institutions and general rules right'. He asks, 'Should we not also have to examine what emerges in the society, including the kind of lives that people can actually lead, given the institutions and rules, but also other influences, including actual behaviour, that would inescapably affect human lives?'20

What is inescapable in human lives, Sen argues, is a complex account of beliefs, motivations and interactions. His theorizing is imbued with respect for these diverse lives in many settings - in any of which people may apply different criteria when claiming what is just or unjust. There is no point, he says, in attempting to find a transcendent principle and calling that 'justice' as it will always leave something behind. Justice in the real world finds a plurality of grounds (or injustices) from which diverse reasoning flows (about justice criteria, what is right, and what

17 Eric Stover, The Witnesses: War Crimes and the Promise of Justice in The Hague (U Penn P 2011) 139.

18 Tom Campbell, Justice (2nd ed., Palgrave Macmillan 2001) 9.

19 Judith Shklar, The Faces of Injustice (Yale UP 1990).

20 Sen (n 15) 10. 
emerges). Different contexts to and components of injustice and the resultant thinking about justice, will elicit attention to different objects of value, says Sen. In the new empirical research discussed in this book, those objects emerged as victim, offender and the wider publics in which the former two are embedded.

Sen further argues that the judgments about justice that revolve around these different objects of value 'take on board the task of accommodating different kinds of reasons and evaluative concerns' for the range of interests that flow from them. How this is done - the process of realization - embraces emotion, reasoning, scrutiny and dialogue. Justice is not an allocation to a single reason. Rather, in the real world, justice inevitably sees 'incomplete resolution'. Plausible outcomes, as 'rankings of alternatives that can be realised', are distinguished from those which might be clearly rejected. Sen proposes that realizable justice makes room for non-congruence and partial resolutions. That is, going 'as far as we reasonably can' is justice in the real world. It can never be absolute. ${ }^{21}$

As a theoretical framework and an analytic argument, Sen creates bridges between accounts that confine justice in the law to its rectificatory purpose, those who present justice as a supreme obligation, those who propose that justice is about maximizing particular goods for the maximum number, and those who see justice as a rights-based conception. He does this principally by presenting justice coming through dialogue. It is decision-making and not solely about decision. Thus, the departure Sen makes from predominant ways of presenting justice is away from transcendence and towards particularity. He proposes an approach to justice that enriches 'reasoned engagement through enhancing informational availability and the feasibility of interactive discussions'. By this I take Sen to mean drawing information from different relevant sources and into deliberation on justice. Perfect justice is not what transpires from such an approach. Rather, we advance towards it. ${ }^{22}$

In the arcane and rather closed world of contemporary criminal justice this type of approach may be tolerated on the fringes in diversionary practices, restorative conferences and therapeutic courts, for example. Dominant legal and scholarly opinion concede that common law criminal justice may benefit from some tinkering but deems the system to be essentially sound. Even though criminal justice systems in liberal democracies lay claim to long histories of organic evolution, there is little acknowledgment that change is a continual process. Tomorrow is viewed

\footnotetext{
21 Ibid., 395, 17, 401.

22 Ibid., xiii.
} 
as more of the same. However, the principles of inclusion and participation that underpin Sen's approach are ribs to an umbrella of justice whether delivered through innovative or conventional mechanisms. ${ }^{23} \mathrm{By}$ drawing on the democratic underpinning to Sen's idea of justice as a discursive exercise, ${ }^{24} \mathrm{I}$ aim to contribute a different and perhaps radical re-positioning of ordinary people in relation to state-centric and lawcentric versions of justice.

\section{JUSTICE INTERESTS AS POLITICAL INTERESTS}

The approach I develop asks for re-examination of the relationship(s) between the state's agents in criminal justice and the publics it encounters and dominates. Institutional interests in justice argue that they represent a higher embodiment of the public in the form of the state. The various publics, it is said, are free to self-regulate with minimum interference. Limits are set in standards and rules for which there exists a normative social consensus. As Antony Duff says, criminal law thus forms a kind of law of the public. ${ }^{25}$ The state then represents that consensus through the criminal law. Should these norms and that law be transgressed, then the state will take what the victimized person proffers and says 'we will take action not for you but for all of you'. Furthermore, the state then says, 'we take the right and responsibility for punishment of those transgressions in order for you not to punish'. Doing these things becomes 'achieving justice' or 'delivering justice' for the public's common good. A universal conception of the common good, in turn, permits sacrifice of individuals or of smaller interests. Ironically, this depiction of a paternalistic and monolithic state lends itself to 'capacious interest' in its controlling and punitive nature. ${ }^{26}$ This vision sutures the idea of

23 Kathleen Daly and Brigitte Bouhours, Conventional and Innovative Justice Responses to Sexual Violence (Australian Institute of Family Studies 2011). These authors use the term 'innovative justice' to describe 'non-traditional' practices and procedures such as circle sentencing, restorative justice and special courts.

24 Dryzek (n 16). An emphasis on discursivity seeks to detach deliberation from institutional structures. It does not, however, pose these democratic dynamics as in conflict.

25 Anthony Duff, 'Towards a Theory of Criminal Law?' (2010) 84(1) Aristotelian Society Supplementary Volume 1.

26 Adam Crawford (ed), International and Comparative Criminal Justice and Urban Governance: Convergence and Divergence in Global, National and Local Settings (CUP 2011) 17. 
justice to both the state and its institutions, as well as to the centrality of punishment. The characterization fuels different narratives. One says that the state and its institutions of justice reflect, adhere to and uphold the values and norms of the public, while at the same time are neutral to and removed from the disputing publics; and the other narrative says that the state sustains social order and control through the harsh instrument of criminal law.

Into the gaps created by this state-centric and schismatic portrayal, the victimized person falls. Indeed, both victim and offender are extracted from the public, de-contextualized and used in performance roles to an institutional script. The narratives characterize victims as moralizing and interested in private goals and therefore not legitimate in a public interest system. So what are they to do? In the main they keep private pain private. They deal with it themselves. They do not approach the state. Only a small proportion turn to criminal justice institutions that claim to represent the public they came from and ask that the injustice they have experienced be acknowledged and addressed.

The larger frame to this story asks what is that relationship between citizens and the state at this site of criminal justice? In answering this question, the presence of the state in the lives of offenders is well recognized, but there is blindness to 'seeing the state' in the lives of victims. ${ }^{27}$ But, if the state is present with both accused and victim and when they are in dispute or conflict with each other, the questions are shared: what does the state owe to each of them at the site of criminal justice? What constraints are placed on citizens and on the state that we can approve of, take to ourselves and impose on others? What is the convergence and divergence between ideas of justice envisaged by state entities and those of its citizens - those directly affected and those more indirectly concerned? These questions go to the interests of persons who are citizens, whether victim or offender. As questions, they are political in that they 'raise and address issues of the moral value or human desirability of an institution or practice whose decisions affect a large number of people'.28 They maintain an open question over the extent to which citizen interests, specifically for those citizens who are victims, coincide with the interests of the state through its justice entities. They

27 Robyn Holder, 'Seeing the State: Human Rights Violations of Victims of Crime and Abuse of Power' in Leanne Weber, Elaine Fishwick and Marinella Marmo (eds) The Routledge International Handbook of Criminology and Human Rights (Routledge 2017) Ch 39.

28 Iris Marion Young, 'Impartiality and the Civic Public' in Seyla Benhabib and Drucilla Cornell (eds), Feminism as Critique (U Minn Press 1987) 73. 
ask for re-examination of the portrayal of public and private interests as rigidly and necessarily distinct. They take seriously the offer of law to citizens. This is a different kind of civic politics to the idea of justice.

\section{CITIZENS, JUSTICE AND DEMOCRACY}

Within my characterization of the debate, claiming the status of 'citizen' for victims may seem obvious to some and deeply troubling to others. As a former practitioner within the criminal justice system, I found the 'victim' label to be sticky as well as unsteady. Its stickiness accreted where, for example, a person had particular characteristics such as being a child or was assessed as traumatized. In which case, special allowances such as witness facilities might be extended to them. The victim label was unsteady in that similar institutional kindnesses were also likely to be extended if the grateful individual performed as a 'deserving' victim. But in the everyday of criminal justice, people as victims were way more complicated and diverse than these representations and woe betides an individual who was angry or not fully literate or demanding in some other way. So I wanted a way of situating any person in relation to state institutions that was more stable, more robust and more comprehensive. Thus, at one level, using citizen-status recognizes that people are more than what happened to them at a moment in time. At another, it arises from noticing how simple and singular representations of victims act for the convenience of authority; how it blurs what is at stake. Citizens have interests in the way public systems work and how they work for all; whereas ideas of victim 'needs' shift people into the personal.

It is important to recognize that, if the demand for inclusion and participation in the justice space challenges narrow representations, it also requires a more rounded portrayal of all involved - without assumptions or absolutes. The citizen term may provide a kind of constitutional stability, but inclusion and participation also argue for recognition of diversity alongside what is shared, and hence recognize context and contingency. The term sees people not solely or only as a victim, or indeed as offender. Neither can be said to be fully represented by the concept of 'community' any more than either 'represent the community'. The citizen term further acknowledges that victims do not speak with one voice, and that the individual and the many victims have different ways of seeing justice. From this perspective, the idea of 'public interest' requires more open acknowledgement of many publics and a range of interests. Including this diversity and difference in participatory practices is core to citizenship in a mature liberal democracy. Inclusion 
and participation both reflect and generate a thick belonging. More than an afterthought to institutional legitimacy, they are foundational.

This call for inclusion and participation in justice is not uncontested. In highly charged debate it is claimed that the crime victim has become the 'idealised political subject ... whose circumstances and experiences have come to stand for the general good'. ${ }^{29}$ The critical attention paid to the role of crime and victimization in the politics of law and order has ensured that the victim identity and experience remains subject to divisive and heated controversy. Justice, it is said, is not only about the victim. Jonathon Simon's work, Governing Through Crime (2007), deals with penal politics in the US but has been influential in Australia as in the UK. He expands arguments against victim inclusion by claiming that new forms of knowledge to bring victim 'truths' into the criminal justice process 'undermine the forms of solidarity and responsibility necessary for democratic institutions'. He infers that citizens who become victims of crime and engage with authorities constitute dangerous anti-democratic actors.

This claim seems to attack the legitimacy of any role in criminal justice for persons as victims, but leaves open the question: what then are citizens expected to be and do when victimized by violence and crime? Leave it to the professionals seemed to be Simon's answer. While unpacking the meaning of justice to ordinary people is the book's focus, questions about what justice was in a democracy and what democracy had to say to justice emerge strongly, some may say rashly.

To help orient readers, I place these questions firmly to the front in this book. Some will find this a challenge, although readers interested in victims and criminal justice will find much that is familiar in these pages. More unfamiliar ideas of normative justice, of the democratic citizen, and of participation and deliberation are subject to early critical attention in the chapters that follow. For now, it is important to know that, following Iris Marion Young, I hold that democratic practice, here through an inclusive norm, is not confined to representational events. Further, and unconfined only to administrative decision-making, I build on the principle of affected interests which says that individuals should be able to influence decisions that affect them'. ${ }^{30}$ I argue that deepening democratic practices within criminal justice deepens justice itself. I also signal an

29 Jonathan Simon, Governing Through Crime: How the War on Crime Transformed American Democracy and Created a Culture of Fear (OUP 2007) 77.

30 Archon Fung, 'The Principle of Affected Interests and Inclusion in Democratic Governance' in Jack Nagel and Rogers Smith (eds) Representation: Elections and Beyond (U Penn P 2013) 237. 
interest in the justice system(s) as institutional arenas 'in which competing demands can be listened to, argued about, and negotiated' ${ }^{31}$ These are civic spaces as well as places of and for law. The possibility of (re)connecting criminal justice to its essentially democratic footings considers the courtroom (and other justice sites) as a place for the validation of belonging, a subjective experience of it, and a site of challenge in which social relations are made and re-made.

Ultimately the book leads readers down two main pathways which I suggest are converging. One contemplates the meaning of justice (mainly) through the eyes of men and women victimized by violence who engage with the criminal justice process. The second considers how the idea of justice may be arrived at. This is about the participatory ideal, its origins in democratic theory and what it says to justice as an institution.

\section{LOCATING THE JUSTICE STUDY}

As a research study, the book is more grounded than these introductory remarks may suggest. It focuses on criminal justice in a common law setting. The institutional setting is evoked through the narratives of Australian and British prosecutors. Victim perspectives are based on exploratory research conducted in the Australian Capital Territory (ACT), a city-state located more-or-less the same distance from Sydney as Manchester is to London, or Washington is to New York. For this component women and men victimized by violence were interviewed on three occasions as their case progressed through the ACT criminal justice process.

In this locality, when a member of the public calls for police assistance following an incident of violence, what follows would look similar to that in most other common law jurisdictions. There may be the taking of statements, gathering of evidence, locating a suspect(s), and consequent decision-making about whether all the information police have gathered amounts to an alleged criminal offence. If a charge results then a prosecution may proceed. All criminal offences in the ACT are prosecuted by the statutory office of the DPP, unlike most other Australian states and territories where police prosecutors deal with summary offences. The function is similar to that of the Crown Prosecution Service (CPS) in England and Wales. In Australia as in Britain, the separation of

31 Ian Loader, 'Policing, Recognition, and Belonging' (2006) 605 The Annals of the American Academy of Political and Social Science 201, 214. 
prosecution from politicians and the political process is jealously guarded, unlike in the US where boundaries are porous. Once a charge is laid, the prosecutor will review the criminal charges, and will (usually) liaise with both the investigating officers and with defence counsel on the nature of the charges and the evidence. The prosecutor will come to her own decision about whether to prosecute and on what charges. If a charge is preferred then it will most likely be heard and finalized in the lower court before a magistrate. Discretion is a huge part of the common law criminal justice process and there are a lot of mays, maybes and likelys.

In many common law jurisdictions including the ACT, victim of crime legislation places some requirements on authorities to give certain information, to provide case status updates, and to provide information on aspects of the process as they affect witnesses. ${ }^{32}$ Authorities may also let a victim know of the availability of opportunities for further input such as a concerns made to bail hearings about individual safety, the making of a Victim Impact Statement (VIS) if an offender is convicted, or submissions made for parole hearings. In the ACT, in matters of domestic assault or sexual assault then - as a result of extensive and sustained local reform efforts - the process of keeping individuals informed is almost uniform. ${ }^{33}$ If it is a different type of assault then it is much more hit-and-miss. ${ }^{34}$ In other common law countries similar scenarios are likely.

While victim legislation often invokes the language of rights, in reality, these are anything but. ${ }^{35}$ At the time of the research, nothing in the ACT victims' legislation constituted a legal duty on any institution or an actionable right for the victim. Having been responsible for this particular statute for 15 years I probably know too much about the compromises justice agencies make in juggling all their functions with the volume of

32 Tyrone Kirchengast, Victims and the Criminal Trial (Palgrave Macmillan 2016).

33 Tracy Cussen and Matthew Lyneham, ACT Family Violence Intervention Program Review Technical and Background Paper No.52 (AIC 2012); Jessica Anderson and others, Evaluation of the ACT Sexual Assault Reform Program (SARP): Final Report Technical and Background Paper No.51 (AIC 2013).

34 For a critical overview of the experiences of crime victims in general conducted when I was the statutory advocate, see Robyn Holder, The Quality of Justice: Operation of the Victims of Crime Act 1994 in the ACT 1996-2007 (VoCC 2008).

35 Rights litigation for victims of crime in the US has evolved considerably in the past decade. See Douglas Beloof and others, Victims in Criminal Procedure (Carolina Academic Press 2017). 
cases. For sure I know that the rights-promoting and rights-protecting role of the statutory advocate for victims of crime has limited authority and few powers. ${ }^{36}$ The inadequacy of rights protection is similar to that for victims in the UK, the US, Canada, and countries in Europe. ${ }^{37}$ Although the ACT has a Human Rights Act, since its commencement in 2004 and at the time of writing, the legislation has not been invoked in relation to victims of crime in any court proceedings. Where law reform submissions from the Human Rights Commission (HRC) have touched on the interests of crime victims, comment has tended to be extremely cautious. ${ }^{38}$ In the UK, human rights have been invoked, for example, in reviewing the investigation of deaths and reviewing the disclosure of complainants' medical records in sexual offence cases. ${ }^{39}$ Overall, however, real rights for people as victims are distant.

\section{STUDYING JUSTICE IN THE REAL WORLD}

In such a complex environment, arguments about what is just/unjust, objective/subjective, and public/private are more than an academic binary. Therefore any examination of justice needs to allow people to voice contradiction and inconsistency even as it attempts to illuminate what is similar and different about the influences on individual thinking

36 Holder (n 34).

37 For the UK see Marie Manikis, 'Navigating Through an Obstacle Course: the Complaints Mechanism for Victims of Crime in England and Wales' (2012) 12 Criminology and Criminal Justice 149; for the US see Douglas Beloof, 'The Third Wave of Crime Victims' Rights: Standing, Remedy, and Review' (2005) 2 BYU Law Rev 255; for Canada see Marie Manikis, 'Imagining the Future of Victims' Rights in Canada: a Comparative Perspective' (2015) 13 Ohio State J Crim Law 163; and countries in Europe see Helga Ezendam, and Frida Wheldon, 'Recognition of Victims' Rights Through EU Action' in Felix Mukwiza and others (eds) Justice for Victims: Perspectives on Rights, Transition and Reconciliation (Routledge 2014) 51.

38 For example, a 2008 submission from the Human Rights Commission in relation to proposed legislative changes aimed at improved protections for victim witnesses in violent and sexual offence proceedings expressed concern about the proposal to restrict direct cross-examination of the complainant witness by the accused in violent matters, and to require an accused to be legally represented. More recently, the HRC and the Victims of Crime Commissioner have produced a practical guide, Victim and Witness Rights under the ACT Human Rights Act 2004 (nd).

39 Equality and Human Rights Commission, Human Rights in Action: Case Studies from Regulators, Inspectorates and Ombudsmen (RIOs) (EHR, 2014). 
and action. Equally, it must notice what is dominating or what is marginal in portrayals of justice, and how realities are structured. Several small workplace studies I had conducted during my time working within criminal justice showed how these 'tensions and conflicts' 40 might be addressed in research design. These studies had exposed the importance of context and timing in survey responses, as well as nuance and perspective. They revealed that victims of all types experienced similar as well as different issues. ${ }^{41}$

One of the workplace studies derived from a group of 39 victims of domestic violence interviewed at the finalization of their matter at court. About a quarter of those first interviewed displayed considerable ambivalence if not hostility to the justice process and its outcome. Twelve months later, 15 of the earlier group were re-interviewed. At this second interview most women reported feeling very or fairly safe, expressed satisfaction and agreed that 'justice was done'. ${ }^{42}$ These results showed that to sample at one occasion locked individuals into a single and simple statement. A static reflection of opinion at a particular point in time becomes the research outcome. However, surveying a person twice showed attitude formation to be a dynamic process and one that was influenced by the context and timing of the questioning.

A second study involved women and men answering a client evaluation survey from a community-based advocacy service - the Domestic Violence Crisis Service (DVCS). In one particular year, 41 per cent of clients indicated that the prosecution of the violent incident was "not beneficial' to them. Nine of those who expressed this view participated in a follow-up telephone interview exploring further their preferences for decision-control, ${ }^{43}$ their justice objectives and indications about future engagement. The sample said that they wanted to be listened to but declined decision-making control and, if faced with similar circumstances in the future, would re-engage with the system even when they had

40 Jan Nespor, 'Morphologies of Inquiry: The Uses and Spaces of Paradigm Proliferation' (2006) 19 International Journal of Qualitative Studies in Education $115,123$.

41 The workplace studies were conducted on (separately) victims of residential burglary, domestic violence, sexual assault and victims of crime as a general category.

42 Robyn Holder and Nicole Mayo, 'What do Women Want? Prosecuting Family Violence in the ACT' (2003) 15 Current Issues in Criminal Justice 525. Only one woman indicated that there had been a new incident of assault.

43 Discussed as victim 'choice' in the literature - see Linda G Mills, 'Killing her Softly: Intimate Abuse and the Violence of State Intervention' (1999) 113 Harvard Law Review 550. 
expressed dissatisfaction. ${ }^{44}$ The study showed the language of personal objectives overlapped with that of official public objectives of justice. These follow-up interviews showed that it was not only important to ask people what they think but why they think it. The perspective that time and distance provided suggested that individuals could and did talk in layered ways and from different positions about the one issue.

Workplace studies such as these have their own unique objectives and characteristics but much of the academic literature examining victims of violence and their experience of criminal justice is also constrained. ${ }^{45}$ The victim of crime constituency is an extremely diverse population. Researchers and activists tend to respond to this diversity by focusing on offence-specific characteristics. The relevance of findings to victims of other types of offences is then open to contention. Commonly, research subjects self-select into studies and are usually sampled at one time and in retrospect. Finally, what is not measured in justice studies is as important as what is and in what context. Measures of emotional resolution, cooperation, safety, fairness and advocacy have been examined. In the main, however, the research on victims and justice has tended to focus on satisfaction. ${ }^{46}$ There is very little knowledge of peoples' journey and still less of the beliefs and expectations they held at the outset. The resulting representation of peoples' perspectives is at once static, flat and passive.

\section{Studying Victims' Ideas of Justice}

The Justice Study sought to do something different. First, it sought to ground people's lived experiences in the broader context of their beliefs,

44 Holder (n 34).

45 See, e.g., discussion from a US perspective in Laura Moriarty and Robert A Jerin (eds), Current Issues in Victimology Research (Carolina Academic Press 2007); from a UK perspective in Jo Goodey, Victims and Victimology: Research, Policy and Practice (Pearson Education 2005). In Australia, while there are a number of small-scale and scattered studies derived from non-academic research, there are no comparable volumes or compilations. The report Victims' Needs, Victims' Rights: Policies and Programs for Victims of Crime in Australia prepared by Bree Cook and others in 1999 comprised a desk-based review of practice.

46 Robyn Holder, 'Satisfied? Exploring Victims' Justice Judgements' in Dean Wilson and Stuart Ross (eds) Crime, Victims and Policy: International Contexts, Local Experiences (Palgrave Macmillan 2015) 184; Malini Laxminarayan and others, 'Victim Satisfaction with Criminal Justice: A Systematic Review' (2013) 8 Victims and Offenders 119. 
expectations and motivations. Second, the nuance with which people struggled to bring to their understanding of what was happening to them and around them, was to be teased out in real time. Thus a longitudinal design was chosen to account for peoples' engagements with different criminal justice agencies. ${ }^{47}$ Semi-structured interviews were conducted with a panel of victims on three occasions: at Time 1 after police had charged an alleged assailant and before the matter went to court; at Time 2 after the matter had finalized in the criminal court; and at Time 3 some six to eight months after court finalization (see the Appendix for more detail). However, keeping track of participants in longitudinal research is challenging. Having commenced at Time 1 with 33 adults (27 women and six men), numbers dwindled. At Time 2 there were 26 (21 women and five men), and by Time 3 the sample ended at 19 (14 women and five men). Overall, 58 per cent of the original sample stayed the full course of the research.

Prospective longitudinal research on victims and justice is infrequent. Some studies, focused on women as victims of domestic violence, have conducted two or three interviews. ${ }^{48}$ One English and one Dutch longitudinal studies interviewed women and men victimized by different offences. The first interviewed a panel of victims of violence on different occasions from initial reporting to police to its outcome. At Time 1, 276 people were interviewed and 215 ( 78 per cent of the original sample) were interviewed at Time 3. Of 54 victims who had applied for compensation, 40 were additionally interviewed on a fourth occasion. 49 The Netherlands' study is more properly a pre- and post-test. This research was designed to evaluate the effects of new guidelines and legislation. Victims of property crimes and minor assault (13 per cent of

47 Robyn L Holder, 'Untangling the Meanings of Justice: A Longitudinal Mixed Methods Study' (2016) Journal of Mixed Methods Research, online DOI: $10.1177 / 1558689816653308$.

48 Those interviewed twice are in Margaret Bell and others, 'Battered Women's Perceptions of Civil and Criminal Court Helpfulness: The Role of Court Outcome and Process' (2011) 17 Violence Against Women 71-88 and Ruth Lewis and others, 'Protection, Prevention, Rehabilitation or Justice? Women's Use of the Law to Challenge Domestic Violence' (2000) 7 International Review of Victimology 179-205; and on three occasions are in Ruth Fleury-Steiner and others, 'Contextual Factors Impacting Battered Women's Intentions to Reuse the Criminal Legal System' (2006) 34 Journal of Community Psychology 327-42, and Judith McFarlane and others, 'Women Filing Assault Charges on an Intimate Partner' (2000) 6 Violence Against Women 396-408.

49 Joanna Shapland, Jon Willmore and Peter Duff, Victims in the Criminal Justice System (Gower 1985) 7-9. 
the sample) were surveyed after their contact with police but prior to contact with the prosecutor and again, some five months later, after the prosecution had 'taken their case into consideration'. A total of 315 people were interviewed before the legislative change and, of these, 193 (61 per cent) completed a second interview. After the changes were put in place, another group of 325 people were interviewed and, of these, 242 (74 per cent) completed a second interview. ${ }^{50}$ Findings from the English and Dutch studies are threaded through discussion of results from the Justice Study in this book.

For this new research, only victims of violence were recruited so as to constrain differences in victimization experience but also in recognition that the experience of violence carries a unique assault on human dignity. This characteristic transcended the gendered nature of individual experiences. None of the people who ultimately participated in the research are intended to stand for all victims. Those recruited were adult women who had been victims of a domestic assault from a male partner or ex-partner, and adult men who had experienced a non-domestic assault from another man. Domestic assault victims were 82 per cent of the study sample at the first interview, 81 per cent of the sample at the second interview, and 74 per cent at the third interview. Individuals were recruited via local victim advocacy and police liaison services in one region. The localized recruitment constrained irrelevant sources of variation in institutional responses. It was also a practical decision about access to and the conduct of face-to-face interviews with individuals over a long period of time. Data collection occurred over four years, from 2009 to 2013.

The Justice Study was initially conceived with a deductive focus on victims' experiences of procedural justice. The Time 1 interview comprised a mix of open and closed questions, some of which were answered directly on a survey form by the interviewee. This instrument contained a number of pre-coded questions that focused on the experience of respect, fairness, and being informed. Questions also asked about the decisions made, whether people felt their views had been considered, and that they had been given an honest explanation for the decisions. They were asked questions that revolved around the legitimacy of the decision-makers and the procedures: were they right, fair and effective. Some questions, asked

50 Combining the two datasets produced $\mathrm{N}=640$ interviews at Time 1 and $\mathrm{N}=435$ at Time 2 (68 per cent). The Netherlands sample comprised victims of theft (73 per cent), assault (13 per cent), vandalism (11 per cent), and crimes against public order (3 per cent) (Jo-Anne Wemmers, Victims in the Criminal Justice System (Kugler Publications 1996) 106, 115, 117). 
on all three occasions, were repeat measures. Other questions were open-ended.

However, as the study progressed to the second and third interviews, the procedural justice focus shifted and became subsumed in a broader conceptualization of justice. The opportunity to be interviewed on three occasions gave people space and time to speak more expansively about the justice they sought. They spoke about what motivated them to mobilize the law, what they sought, and what their feelings were about the person who had been violent towards them. I asked about their perceptions, expectations and experiences of the institutions of police, prosecution and court. Perhaps above all I asked for their reasoning. From these open-ended questions, more thematic and critical perspectives emerged. In discussing these perspectives in the chapters that follow, I describe respondents in different ways as lay participants, lay people, victims and as citizen-victims. When quoted, each person is given a pseudonym.

At the first interview people were also asked closed questions derived from other Australian surveys so as to locate them within a national sample. One survey examined the micro foundations of Australian democracy and asked about trust, beliefs and values. ${ }^{51}$ Another looked at citizen attitudes towards crime and policing, ${ }^{52}$ and a third examined attitudes to sentencing and confidence in courts. ${ }^{53} \mathrm{~A}$ number of scales were created from which to compare the study group with these larger samples. Because of the large $\mathrm{N}$ differences between the national samples and that in the Justice Study, only broad comparisons are made.

\section{Studying Prosecutors and Their Ideas of Justice}

This focus on individual victims, however rich and thick, would only enable a partial telling of the everyday justice story. The institutional landscape also needed to be brought into view. For this purpose, the book

51 Valerie Braithwaite, The Community Hopes, Fears and Actions Survey: Goals and Measures Working Paper No.2 Centre for Tax System Integrity, The Australian National University 2001. The sample was N=3,558.

52 Kristina Murphy and others, 'The 2009 Public Safety and Security in Australia Survey: Survey Methodology and Preliminary Findings' (2010b) Working Paper No.17 Alfred Deakin Research Institute, Deakin University, Geelong. The sample was $\mathrm{N}=1,204$.

53 Geraldine Mackenzie and others, 'Sentencing and Public Confidence: Results from a National Australian Survey on Public Opinions towards Sentencing' (2012) 45 ANZJC 45. The sample was $\mathrm{N}=6,005$. 
focuses on the public prosecutor. I first conducted semi-structured interviews with a small number of ex-Directors of Public Prosecution in Australia. Their justice story was dominated by a picture of criminal justice as a civilizing force and of their role as protectors of that tradition. A second phase of interviews conducted in 2016 with serving and ex-senior prosecutors in the UK demonstrated that the storybook was similar but with some intriguing differences. All prosecution interviewees were assured that no personal or professional characteristics would be used to identify them. Their comments are not individuated for this reason, a decision which highlights an institutionalized narrative.

In combination, the 12 prosecutors were invited to reflect on the underlying features to the concept of 'public interest' and where, if at all, private citizens stood within the criminal justice system. I also asked what conception of justice they carried with them in their working lives, and how they understood the different demands that victims put on prosecuting authorities.

\section{Analysis Overview}

Although there are obvious differences between the lay and legal interviewees in the Justice Study, several common conceptions of justice guided analysis of their narratives. The conceptions, drawn from political philosophy and social psychology, emphasized the normative and dutyoriented features of justice, ideas of fairness and accountability, moral and practical reasoning, relational and contextual aspects, process as well as outcome, and the public and private reach of justice. In addition, for the lay group, a number of repeat scale measures anchored the narrative analysis. These included 'overall satisfaction' and 'justice being done'. Although I am critical of victim research that splinters people's stories, my analysis did not fully overcome the problem.

The analysis of the lay sample primarily treats them as a single population rather than disaggregating by gender or nature of the offence. However, at Time 1 the difference between the sub-samples of domestic assault victims $(\mathrm{N}=27)$ and non-domestic assault victims $(\mathrm{N}=6)$ allowed some limited disaggregation. A separate analysis of the views of the women as victims of domestic violence is published elsewhere. ${ }^{54}$

In the end, the meanings given to the idea of justice by both victims and legal officials were far richer than the original procedural focus.

54 Robyn Holder and Kathleen Daly, 'Sequencing Justice: A Longitudinal Study of Justice Goals of Domestic Violence Victims' (2017) British Journal of Criminology online doi:10.1093/bjc/azx046. 
Ironically, the courtroom created a space where the two groupings shared (if different) interests in justice - though this is unacknowledged and unrecognized. Neither of the lay or legal narratives is claimed as truth or as representative, but their ideas of justice appeared as a dynamic construct. The analysis of these constructs attempts to make visible that which power renders invisible, and to scope multi-dimensional meaning where one (or even two) predominates. Feminist and other critical theorists encourage not only different ways of seeing, but also demand interrogation of dominant world-views. In the institutional setting, my analysis followed Pierre Bourdieu in order to examine ways in which the 'force of law' reveals and deconstructs power relations. ${ }^{55}$ Developing upon Bourdieu's approach, I mine historical legacies and justifications that the interviews with public prosecutors revealed. This critical approach enables us to see 'what the law does' as well as to understand 'what the law is'.56

One final 'real world' comment needs to be made. I began and remain deeply cognisant of critical scholarly opinion that the law routinely and persistently fails to live up to its promise. But I do not subscribe to positions that would see it diminished or abolished. Undoubtedly the 'myth of rights' described by Stuart Scheingold seduces attention from the more 'ambivalent relationships to law and legal institutions' that research reveals. ${ }^{57}$ But I have seen what violence does and the power it wields in the lives of women and men. I know there is a place for guardians of individuals and of the public interest. The problem is how comprehensively and exclusive that place is conceived.

\section{PLAN OF THE BOOK}

The book is structured in a slightly unorthodox manner with a preponderance of conceptual discussion in Chapters 1 to 3 . These explore the literature; first, on justice and second, on legal mobilization. Usually this type of conceptual and theoretical discussion is restricted to an introductory chapter or inflects the final. However, I place it early to help the reader orient to how later analysis of the three waves of victim interview

55 Pierre Bourdieu, 'The Force of Law: Towards a Sociology of the Juridicial Field' (1987) 38 Hastings L J 814.

56 Susan Silbey, 'After Legal Consciousness' (2005) 1 Annual Rev Law and Society 323, 324.

57 Ibid., 340. Stuart Scheingold, The Politics of Rights (2nd ed., U Mich Press 2004). 
is developed. Chapter 2 opens with a brief critical examination of contemporary representations of victim interests in justice. I interrogate the nature of the 'public' in the civic realm, in the criminal law, and as an embodiment of difference. I particularly draw on Iris Young's critique of the private/public divide and the manner in which this serves a picture of justice as universal, rational and objective. I then explore the idea of justice through selected literature from political philosophy and the social sciences. Given the enormous breadth of this work, a number of dimensions to the idea of justice are developed that, in later chapters, then serve to frame both victims' and professionals' narratives as well as act as analytic codes. Specifically, these dimensions pose justice as normative guide, as duty, as accountability, as fairness, as relational, and as contextual. In order to accentuate the critical turn of the analysis, I expand on justice as an interpretive conception and as a heuristic in social and political consciousness.

In Chapter 3 I sketch ways in which law is both 'strange and familiar', accessible and remote to people who have experienced injustice. ${ }^{58} \mathrm{I}$ emphasise the influences at work that open or shut down awareness of law whether as a boundary or an available resource. From an analysis of theories of legal mobilization, I identify and highlight key concepts as either 'top down' or 'bottom up'. The distinction allows us to see that the movement people make from their everyday world to connect with legal authority is not a simple and direct instrumental choice, but is beset by complex decision-making. I outline the research that shows recourse to law to be a minority exercise and disentangle the evidence on victim motivations. The pathways (interpersonal, social and institutional) that are available (and not available) to people following a disruptive event are presented as both real and imagined; and as created by them as well as for them. There is nothing automatic or certain about turning to the law following violence.

Stepping from these theoretical and review chapters, Chapters 4-8 comprise findings from the Justice Study that are new to the field. In Chapter 4 I introduce perspectives on justice from serving and ex-public prosecutors. These perspectives are situated in the present day and as products of certain historic transitions that are selectively told. I unpick core prosecution concepts of independence and public interest. The construct of public interest is presented as both boundary setting and as a gap in the rules in which discretion flourishes.

58 Patricia Ewick and Susan Silbey, The Common Place of Law (U Chicago P 1998) 16. 
Chapter 5 focuses in to explore the grounded perspective of the 33 individual men and women I interviewed who turned to the law following violence. They are re-framed as voices from below; less as 'victim' and more as 'ordinary people', an alternative rendering that is drawn from cultural theory. From here I then link people to their citizen-status situated in a political arrangement to authorities. The lay participants are introduced and located within data drawn from larger Australian samples. People's comments about law and justice are sharpened by reflection on their objectives and reasoning in reporting the violent incident to police.

Looking through a substantive justice lens, Chapter 6 explores what matters in the idea of justice. Using Gromet and Darley's concept of justice goals, ${ }^{59} \mathrm{I}$ show these are multiple and face in different directions. I develop the notion of a justice trilogy to encompass the concerns the participants show for themselves as victim, for the offender and their community of others. The analysis of victims' multiple goals presents an understanding of fairness that is both contextual (individual, social and institutional) and consequential (constructed over time and experience). In Chapter 7, I shift to examine how people's ideas about justice hold up against their lived experience within the criminal justice system. Here, both procedural and an outcome justice lens illuminate what lies behind assessments of satisfaction. To this analysis are added people's reflections about their treatment. In the different contexts of the justice process the idea of justice becomes slippery and unstable.

Chapter 8 narrows discussion to those lay participants who contributed in all three interviews comprising the longitudinal study. I do this in order to explore how participation works and the extent to which individuals might want to influence decision-making. The discussion is placed within a broader literature about citizen and user participation in public and service spaces, and describes participation in the justice sphere as a unique citizenship practice. I demonstrate that some participatory roles in criminal justice derive from state-centric priorities around the 'decision' and fail to delineate the nature of the interests that the state and victims may (or may not) share. Rather than insisting upon a rigid distinction between public and private, I show that these interests are co-determining. The architecture of the criminal justice system enables

59 Dena Gromet and John Darley, 'Punishment and Beyond: Achieving Justice through the Satisfaction of Multiple Justice Goals' (2009) 43 Law and Soc Rev 1. 
the sequencing of justice objectives and a series of spaces in which mutually constitutive public and private interests can be articulated.

In the final chapter I develop, from the key findings of the research, an argument for participatory justice that draws upon deliberative democracy literature. I argue that not only is justice foundational to the concept of citizenship, but that people's interaction with justice institutions, as a deliberative system, is constitutive of democratic governance. I contend that the exclusion of constituencies of directly affected interests represents a democracy deficit and one that trends against contemporary demands for involved publics and the integration of pluralism within justice. 